\title{
Erratum to: Follow-up of coiled intracranial aneurysms: comparison of 3D time-of-flight and contrast-enhanced magnetic resonance angiography at $3 T$ in a large, prospective series
}

Laurent Pierot • Christophe Portefaix • Anne Boulin • Jean-Yves Gauvrit

Published online: 14 July 2012

(C) European Society of Radiology 2012

\section{Erratum to: Eur Radiol}

DOI 10.1007/s00330-012-2466-6

Due to a transcription error, several images in the article entitled "Follow-up of coiled intracranial aneurysms: comparison of 3D time-of-flight and contrast-enhanced magnetic resonance angiography at $3 \mathrm{~T}$ in a large, prospective series", were incorrectly numbered:

Figure $1: 1 \mathrm{C}$ is in fact $1 \mathrm{~B}, 1 \mathrm{E}$ is $1 \mathrm{C}, 1 \mathrm{~B}$ is $1 \mathrm{D}$, and $1 \mathrm{D}$ is $1 \mathrm{E}$.

Figure $2: 2 \mathrm{C}$ is in fact $2 \mathrm{~B}, 2 \mathrm{E}$ is $2 \mathrm{C}, 2 \mathrm{~B}$ is $2 \mathrm{D}$, and $2 \mathrm{D}$ is $2 \mathrm{E}$.

Figure $4: 4 \mathrm{C}$ is in fact $4 \mathrm{~B}, 4 \mathrm{E}$ is $4 \mathrm{C}, 4 \mathrm{~B}$ is $4 \mathrm{D}$, and $4 \mathrm{D}$ is $4 \mathrm{E}$.

We apologise for this error in this complex set of images; the error was multifactorial.

The online version of the original article can be found at: http:// dx.doi.org/10.1007/s00330-012-2466-6.

L. Pierot $\cdot$ C. Portefaix

Department of Radiology, Maison Blanche Hospital,

University of Reims,

Reims, France

C. Portefaix

CReSTIC SIC EA3804, University of Reims,

Reims, France

\section{A. Boulin}

Department of Neuroradiology, Foch Hospital,

Suresnes, France

J.-Y. Gauvrit

Department of Radiology, CHU Rennes, University of Rennes,

Rennes, France

\section{Pierot $(\bowtie)$}

Service de radiology, Hopital de la Maison Blanche - CHU,

45, rue Cognacq Jay,

51100 Reims, France

e-mail: 1pierot@gmail.com 